\title{
The Jatropha leaf curl Gujarat virus on infection regulates the sugar and tricarboxylic acid cycle metabolic pathways in Jatropha
}

\section{Prashant More}

Central Salt and Marine Chemicals Research Institute CSIR

\section{Parinita Agarwal}

Central Salt and Marine Chemicals Research Institute CSIR

Pradeep K. Agarwal ( $\sim$ pagarwal@csmcri.res.in )

Central Salt and Marine Chemicals Research Institute CSIR https://orcid.org/0000-0002-2588-9622

\section{Research Article}

Keywords: JLCUGV, GC-MS, polyols, carboxylic acids, fatty acids, polyphenols, TCA

Posted Date: February 16th, 2021

DOI: https://doi.org/10.21203/rs.3.rs-230203/v1

License: (c) (i) This work is licensed under a Creative Commons Attribution 4.0 International License.

Read Full License 


\section{Abstract}

Jatropha, a popular biodiesel crop, suffers severe losses due to Jatropha leaf curl Gujarat virus (JLCuGV) infection in Gujarat (India). Gas chromatography-mass spectrometry (GC-MS) analysis of healthy and infected tissue revealed that the metabolites like sugars, polyols, carboxylic acids, fatty acids, polyphenols, and amino acids were regulated on JLCuGV infection. The sugars (glucose, sucrose, and fructose) increased, while carboxylic acids (malic acid, citric acid and quinic acid) and polyols (galactinol, butanetriol, triethylene glycol, myo-inositol, erythritol) decreased remarkably in infected Jatropha tissue. The increased accumulation of polyphenols in JLCuGV infected tissue suggests activation and involvement of polyphenol biosynthesis pathways as a defence response to geminivirus. All these metabolic variations indicated that sugar metabolism and tricarboxylic acid (TCA) cycle pathways are regulated as a defence response as well as a disease development response to geminivirus infection in Jatropha.

\section{Introduction}

Jatropha (Jatropha curcas L.) is an economically important biodiesel crop which grows on wastelands. The Jatropha biodiesel is successfully used to run the vehicles without any modifications in engines [1, 2]. Jatropha, being a non-edible crop, serves as a better and viable option compared to other food crops like rapeseed, sunflower, palm, soybean, corn, sugarcane, etc. for biofuel production. Recently, Jatropha biofuel was for the first time used in aircraft (Spicejet's Bombardier Q400) [3], indicating its high efficiency as fuel. The major problem in Jatropha biodiesel production is its lower yield because of various diseases like collar rot, leaf spots, powdery mildew, seedling blight, seedling stem rot and viral infestation [4]. The leaf curl mosaic disease caused by geminivirus belonging to Begomovirus genus and is a severe threat to Jatropha, causing up to $80 \%$ yield losses [5].

The metabolic changes in response to fungal and bacterial disease infection are well studied in plants as compared to the viral infection [6]. The interaction between the host plant and geminivirus changes the plant's physiology leading to the development of disease symptoms [7]. The metabolite changes are also among the typical responses of host plant after virus infestation [6]. The qualitative and quantitative variation in the plant's metabolite variation can help understand the plant physiological response to virus infection. Due to systemic infection, entire plant physiology is affected in geminivirus infected plant involving disruption in plant's replication machinery, metabolic resources, gene regulation which negatively affects the plant's growth and development [7]. Still, the symptoms are more prominent on leaves of the plant. The altered cellular metabolism helps the virus to multiply in the host [8]. Plants also tend to produce some metabolites which act as a defence against virus infection such as amino acids, secondary metabolites etc. $[9,10]$. The secondary metabolites like terpenes/terpenoids, flavonoids, alkaloids, and phenol derivatives are mainly produced from primary metabolites like sugars, amino acids, carboxylic acids, and their concentration gets affected on various virus infection in plants [10]. The concentration of phenylpropanoids and the flavonoids also gets increased as a defence response against geminivirus infection [9]. The terpenoid biosynthesis suppressed after geminivirus infection in tomato 
[11], suggesting that depletion of terpenoids might be necessary for geminiviruses to establish a successful infection. The virus infection in plants causes an alteration in the metabolism of carbohydrates, starch, sugars and amino acids [12], indicating that the virus infection disrupts the metabolic pathways and damages the plant physiology. The carboxylic acids, which are the by-products of tricarboxylic acid (TCA) cycle, also get affected in geminivirus infection [9].

The studies on metabolite variations on geminivirus infection in Jatropha are limited. An earlier study by Sood and Chauhan [13] documented the upregulation of terpenoid biosynthesis and fatty acid metabolism genes, but the actual metabolite variation not studied. The metabolic changes were studied in J. curcas with Jatropha mosaic virus (JMV) infection by Sidhu et al. [14] using high-resolution magic angle spinning (HR-MAS) NMR spectra, and only 11 metabolites were detected. The comparative metabolic profiles of an infected and healthy plant can help to unravel the changes in biochemical pathways on geminivirus infection. Earlier, we had identified the Jatropha leaf curl Gujarat virus (JLCuGV) infecting the Jatropha from Gujarat [15]. In the present study, the modifications in metabolite profiling were analysed to understand the regulation of the metabolic pathways on natural JLCuGV infection in Jatropha.

\section{Materials And Methods}

\section{Plant material}

The plants with similar developmental stage were selected for sample collection. The healthy (young plants with no symptoms, Fig. 1A) and naturally infected (young plants showing leaf curl symptoms all over the plant, Fig. 1B) leaves of J. curcas from CP9 (IC 565735), an elite Jatropha accession, with high seed and oil yield [16] were collected, with three biological replicates each in the morning, from Nesvad (altitude-314 ft, N 21 30' 494" E 072 02' 185") experimental fields of CSIR-CSMCRI, Gujarat. Jatropha plantations at Nesvad experimental field were maintained with practices followed as per Anand et al. [17]. The collected leaf samples were stored at $-80^{\circ} \mathrm{C}$ until use.

\section{Detection and Identification of begomoviruses}

The DNA from collected Jatropha leaf samples was isolated using a method specifically developed for Jatropha [18]. The isolated DNA (100 ng) then used as template for detecting the presence of begomovirus by PCR using primers VirLCF (5'-GACCGCATAAATAATTGTGTGGGCCG-3') and VirLCR (5'GCTGTAGAAATATATGCGTATTTTC-3'), which were designed specifically for detecting the begomoviruses infecting Jatropha. The complete DNA-A of JLCuGV cloned in pBluescriptll KS(+) vector from our earlier study [15] was taken as a positive control.

\section{Gas chromatography-mass spectrometry (GC-MS) analysis}

After confirming the presence and absence of JLCuGV in collected infected and healthy leaf samples, respectively, we used these samples for GC-MS analysis. The entire leaves were ground to a fine powder 
using liquid nitrogen and $100 \mathrm{mg}$ of crushed powder tissue taken for sample preparation. The sample preparation and derivatisation by N-methyl-N-trimethylsilyl trifluoroacetamide (MSFTA) was carried out as given in Lisec et al. [20]. The derivatised samples were then transferred into glass vials suitable for GCMS analysis. The GC-MS analysis was carried out as given in Paidi et al. [21]. Three replicates of each sample were taken for analysis.

\section{Statistical analysis}

The mean values and standard deviations were calculated of three independent biological

replicates. Two paired sample t-test was employed as the statistical method to determine the significance of the difference in concentration of all the detected metabolites in healthy (control) and virus-infected leaf tissue of Jatropha and $p<0.05$ was considered to be statistically significant.

\section{Results}

\section{Geminivirus infection in Jatropha}

The Jatropha plants of different accessions like CP9, PCM, Ranpur, Shyamalaji, and Zanjmer were infected by geminivirus at Nesvad, Chorvadla and Bhadraval field sites of CSIR-CSMCRI with $>70 \%$ geminivirus disease incidence [15]. The symptoms were similar in all accessions with severe leaf curling. In the present study, we used only CP9 accession from Nesvad location as it is economically more important due to its high seed and oil yield [20]. The healthy plants showed no leaf curl mosaic symptoms (Fig. 1A). In the case of younger plants, all the leaves showed the prominent yellow mosaic curl symptoms (Fig. 1B), while in old plants, only the new young leaves showed the prominent yellow mosaic curl symptoms (Fig. 1C). The virus responsible for causing the leaf curl disease was identified as JLCuGV in our earlier study [15]. The collected Jatropha leaf samples (three replicates each of healthy and infected leaf tissue) were checked for geminivirus infection. Only those samples showing leaf curl symptoms were identified as positive by PCR (Fig. 1D) and were used for the metabolite analysis.

\section{Metabolite profiling in healthy and infected Jatropha leaf}

The metabolite analysis of geminivirus infected and healthy Jatropha leaf tissue revealed an accumulation of 98 total metabolites. (Table 1). Out of them, 49 metabolites were detected in both tissues, 28 and 21 unique metabolites in healthy and infected tissue, respectively (Fig. 2A, Table 1). All the detected metabolites were categorised in eight different groups like alkanes, amino acids, carboxylic acids, fatty acids, fatty alcohols, polyols, polyphenols and sugars. The compounds like Dgalactopyranoside and 2-ketoglutaric acid were detected in higher amount in healthy tissue only, while hexonic acid and 4- Aminobutyric acid were two compounds which were detected in higher concentration in only infected tissue (Table 1).

Sugars were the largest group of compounds, and the amount of sugar was more in the infected tissue (48\%) than healthy tissue (35\%; Fig. 2B). Twelve different sugars were identified in both healthy and 
infected tissue. In the infected tissue, sugars like fucopyranose, trehalose, glyceryl-glycoside, and mannobiose decreased, while sucrose, glucose, galactoside, glucopyranose, lactose and fructose increased. L-fucopyranose decreased by 2 -fold, while lactose and fructose increased significantly by 2.14 and 3.23-fold, respectively (Table 2, Fig. 3).

The carboxylic acid was the second largest group identified with $26 \%$ and $16 \%$ concentration in the healthy and geminivirus infected tissue, respectively (Fig. 2B). Fourteen carboxylic acids were detected in both healthy and infected tissue. Carboxylic acids like glutaric acid, malic acid, quinic acid, pentadecafluorooctanoic acid, succinic acid, citric acid and threonic acid were significantly decreased, while glyceric acid was significantly increased in infected tissue (Table 2, Fig. 3). In the infected tissue maximum decrease of 24.5-fold was observed in glutaric acid, $>2$-fold decrease in malic acid, quinic acid, galactaric acid, methoxyacetic acid, pentadecafluorooctanoic acid, succinic acid as compared to healthy tissue. The glyceric acid, gluconic acid, fumaric acid, and shikimic acid increased by $<1$.2-fold in infected tissue (Table 2).

In addition to sugars and carboxylic acids, the next larger group was polyols. The polyols accumulation was more in healthy tissue (23\%) as compared to infected tissue (19\%; Fig. $2 \mathrm{~B})$. Total nine polyols were detected in both healthy and infected tissue. Amongst them, galactinol, triethylene and myo-inositol decreased significantly, while deoxypentitol increased significantly in the infected tissue (Fig.3). Galactinol decreased by 2.04-fold, while deoxypentitol increased by 2.77-fold in infected tissue (Table 2).

Similarly, the concentration of fatty acids was also lower in infected tissue (6\%) as compared to healthy tissue (8\%). Total five fatty acids were detected, and among them, docosanoic acid, palmitic acid, and stearic acid were significantly decreased by $>1.5$-fold, while butanoic acid octatriacontyl pentafluoropropionate were unaffected (Table 2, Fig. 3). The polyphenols were more in infected tissue $(10 \%)$ than healthy tissue (6\%). Total three polyphenols detected in both tissue and among them, quercetin was increased significantly by 3.7 -fold in infected tissue (Table 2, Fig. 3).

The other compounds like fatty alcohols, alkanes and amino acids were detected in less quantity $(<2 \%)$ in both the healthy and infected tissue, furthermore their concentration decreased on the infection (Fig. 2B). Amongst them, L-serine is the most affected compound with a 19.67-fold decrease in infected tissue (Table 2). The identified compounds mostly participate in sugar metabolism and TCA cycle. Their variation in healthy and infected tissue is shown in the interlinked pathway of sugar metabolism and TCA cycle (Fig. 4). Sugars (glucose, fructose, sucrose, galactoside, glucopyranose and lactose) were mostly increased in infected tissue, while the compounds generated from the metabolism of these sugars like sugar alcohols (butanetriol, erythritol, myo-inositol, galactinol) and carboxylic acids (galactaric acid threonic acid and ribonic acid) were higher in healthy tissue. Glutaric acid, a by-product of amino acid metabolism, was also higher in healthy tissue. Similarly, compounds of TCA cycle (citric acid, succinic acid and malic acid) and derivatives of fatty acids (docosanoic acid, dihydroxybutanoic acid, palmitic acid and stearic acid) were more in healthy tissue (Fig. 4). 


\section{Discussion}

The young Jatropha plants infected with JLCuGV showed the mosaic curl symptoms all over the plant, suggesting that early infection in the young plant could spread to the entire plant. In contrast, in mature Jatropha plant, only new young leaves show mosaic curl symptoms, indicating that the Jatropha plants infected in early-stage were highly damaged. The extent of damage reduced with delay in infection [22]. The JLCuGV successfully replicated in young leaf cells undergoing endoreduplication [23], but the mature leaves of matured Jatropha plant remained unaffected, indicating the restriction of virus spread in mature cells, leading to less damage.

The compatible plant-virus interactions result in disease development and lead to changes in gene expression and metabolite content. In Jatropha, the regulation of the hormonal signalling of salicylic acid $(\mathrm{SA})$, jasmonic acid (JA), abscisic acid (ABA), auxin and ethylene was reported during the geminivirus infection $[13,24]$. As the previous study by Sidhu et al. [35] showed limited metabolite analysis, we performed the total metabolite analysis using GC-MS profiling of Jatropha leaf to reveal the changes in different metabolite pathways during geminivirus infection. In the present study, 98 metabolites were identified based on GC-MS analysis of infected and healthy Jatropha plant, and the analysis revealed differential metabolite profiling.

The sugars were increased in infected tissue of Jatropha because the sugar metabolism was negatively affected and resulted in decreased production of polyols and carboxylic acids, which are the by-products of sugar metabolism (Fig. 4). The similar negative regulation of sugar metabolism in tobacco plants due to JLCuGV infection was also reported in our earlier study [15]. Impaired sugar transport may be the reason for the increased sugar content during virus infection [25]. Among polyols, galactinol, which was earlier reported as a signalling molecule to trigger the plant defence on bacterial pathogen attack [26], was decreased by $>2$ fold in infected tissue, indicating that galactinol triggered plant defence might not be activated on JLCuGV infection. Myo-inositol, which plays a role in the membrane and cell wall synthesis [27], decreased in infected tissue, indicating the impaired cell wall biosynthesis in infected Jatropha tissue. The carboxylic acids decreased in infected Jatropha tissue, and the similar result reported in the Papaver somniferum on Ageratum enation virus (AEV) infection [28] and in our earlier study in tobacco on JLCuGV infection [15]. The increase in sugars and decrease in polyols, carboxylic acids in infected Jatropha tissue indicates that both sugar metabolism and TCA cycle are affected in infected Jatropha tissue (Fig. 4). The interruption in the TCA cycle and low accumulation of glucose and sucrose was also reported earlier in Jatropha infected tissue by Sidhu et al. [14].

Fatty acids, which are the precursors of the JA biosynthetic pathway [29], decreased in infected Jatropha tissue, indicating the JA mediated defence response impaired in infected tissue. The similar decrease in fatty acid composition was observed on TRV infection in Arabidopsis [6]. The polyphenols were more in infected tissue, indicating that these polyphenol biosynthesis pathways are activated in response to geminivirus attack. The polyphenols were reported to be produced in the plant to protect them from against pathogens and phytophagous insects [30]. The phenolic compounds also accumulated in 
response to geminivirus infection in capsicum [31] and pumpkin [32], and the phenolic compounds facilitate the formation of physical barriers to restrict the systemic spread of the virus [33]. Out of the common compounds, which were identified in both healthy and infected Jatropha leaf tissue, the concentration of L-serine, a polar amino acid playing a fundamental role in metabolism and cell signalling [34], showed maximum decrease in infected tissue, indicating disturbed metabolism and cell signalling in Jatropha after geminivirus infection.

The compound like hexonic acid was detected only in infected Jatropha tissue in a higher amount, indicating that its synthesis gets activated with geminivirus infection. It was earlier reported that hexonic acid is stress signalling molecule providing hexanoic acid-induced resistance ( $\mathrm{Hx}$-IR) against several pathogens like Botrytis cinerea and Pseudomonas syringae in tomato and Alternaria alternata in citrus $[35,36]$. The hexonic acid also blocked the systemic spread of Melon necrotic spot virus (MNSV; family Tombusviridae) by activating SA pathway and increasing the callose deposition in melon [37]. In Jatropha, both the JA and SA pathway get activated on geminivirus infection [13], suggesting that hexonic acid might be involved in activation of these pathways in Jatropha with geminivirus attack. After hexonic acid, the second-highest compound identified in JLCUGV infected leaf tissue of Jatropha was 4aminobutyric acid (gamma-aminobutyric acid (GABA)). A similar increase in GABA concentration in infected Jatropha leaf was observed by Sidhu et al. [14]. GABA found to accumulate in both abiotic and biotic stress [38]. Although its role in geminivirus infection is still not reported, its accumulation increases with herbivores insect feeding [39], so the whitefly feeding might have stimulated GABA accumulation in Jatropha infected leaves. The 2-ketoglutaric acid (a-ketoglutarate), an intermediate of the TCA cycle

which determines the overall rate of a citric acid cycle [40], was detected only in the healthy tissue of Jatropha, indicating that the TCA cycle was efficiently functioning in healthy tissue.

In conclusion, the metabolite analysis in healthy and infected Jatropha leaves revealed that the sugar metabolism and TCA cycle pathway were negatively affected in infected leaves, leading to increased sugar content and decreased polyols and carboxylic acid content. The metabolite flux of Jatropha plant showed JLCuGV infection impairs plant physiology and development of leaf curl mosaic symptoms. The metabolites were regulated as defence response and also as a consequence of the disease incidence in Jatropha after JLCuGV infection.

\section{Declarations}

\section{Author contributions}

PM performed major experiments. PA helped in designing and executing experiments. PA and PKA conceived and coordinated the experiments. All authors have contributed to MS writing and approved the final manuscript.

\section{Compliance with ethical standards}

\section{Conflict of interest}


The authors state that there is no conflict of interest regarding the publication of this article.

\section{Acknowledgements}

CSIR-CSMCRI Communication No.-PRIS 135/2020. The authors are thankful to the Department of Science and Technology (DST) and Council of Scientific and Industrial Research (CSIR), New Delhi, India. PA acknowledges the financial support from DST-WOS-A scheme. PM is supported by the DST-INSPIRE SRF fellowship.

\section{References}

1. Wani SP, Chander G (2012) Jatropha curcas biodiesel, challenges and opportunities: Is it a panacea for energy crisis, ecosystem service and rural livelihoods? In: Jatropha, Challenges for a New Energy Crop. Springer New York, pp 311-331

2. Ghosh A, Chikara J, Wheeler C (2012) Determination of the Economic Viability \&amp; Technical Feasibility of Commercial Jatropha Curcas Production for Generation of Jatropha oil as Bio-Fuel Feedstock from Wasteland: Final Technical Report on Life Cycle Impact Assessment of Jatropha Cultivation. Golden, CO (United States)

3. Upadhyay K (2018) SpiceJet flies India's first biofuel flight, from Dehradun to Delhi. The Indian Express

4. More P, Agarwal P, Agarwal PK (2019) Geminiviruses: Molecular biodiversity and global distribution in Jatropha. Physiol Mol Plant Pathol 108:. https://doi.org/10.1016/j.pmpp.2019.101439

5. Kancharla N, Jalali S, Narasimham J V, et al (2019) De Novo Sequencing and Hybrid Assembly of the Biofuel Crop Jatropha curcas L.: Identification of Quantitative Trait Loci for Geminivirus Resistance. Genes (Basel) 10:. https://doi.org/10.3390/genes10010069

6. Fernández-Calvino L, Osorio S, Luisa Hernández M, et al (2014) Virus-induced alterations in primary metabolism modulate susceptibility to Tobacco rattle virus in arabidopsis. Plant Physiol 166:18211838. https://doi.org/10.1104/pp.114.250340

7. Culver JN, Padmanabhan MS (2007) Virus-induced disease: Altering host physiology one interaction at a time. Annu. Rev. Phytopathol. 45:221-243

8. Thaker SK, Ch'ng J, Christofk HR (2019) Viral hijacking of cellular metabolism. BMC Biol. 17:59

9. López-Gresa MP, Lisón P, Kim HK, et al (2012) Metabolic fingerprinting of Tomato Mosaic Virus infected Solanum lycopersicum. J Plant Physiol 169:1586-1596.

https://doi.org/https://doi.org/10.1016/j.jplph.2012.05.021

10. Mishra J, Srivastava R, Trivedi PK, Verma PC (2020) Effect of virus infection on the secondary metabolite production and phytohormone biosynthesis in plants. 3 Biotech 1-16. https://doi.org/10.1007/s13205-020-02541-6

11. Luan JB, Yao DM, Zhang T, et al (2013) Suppression of terpenoid synthesis in plants by a virus promotes its mutualism with vectors. Ecol Lett 16:390-398. https://doi.org/10.1111/ele.12055 
12. Ramesh S V., Sahu PP, Prasad M, et al (2017) Geminiviruses and plant hosts: A closer examination of the molecular arms race. Viruses 9

13. Sood A, Chauhan RS (2017) Comparative NGS Transcriptomics Unravels Molecular Components Associated with Mosaic Virus Infection in a Bioenergy Plant Species, Jatropha curcas L. Bioenergy Res 10:129-145. https://doi.org/10.1007/s12155-016-9783-6

14. Sidhu OP, Annarao S, Pathre U, et al (2010) Metabolic and histopathological alterations of Jatropha mosaic begomovirus-infected Jatropha curcas L. by HR-MAS NMR spectroscopy and magnetic resonance imaging. Planta 232:85-93. https://doi.org/10.1007/s00425-010-1159-0

15. More $P$, Agarwal $P$, Anand $A$, et al (2021) Artificial miRNA mediated resistance in tobacco against Jatropha leaf curl Gujarat virus by targeting RNA silencing suppressors. Sci Rep 11:890. https://doi.org/10.1038/s41598-020-79134-z

16. Singh S, Prakash A, Chakraborty NR, et al (2016) Trait selection by path and principal component analysis in Jatropha curcas for enhanced oil yield. Ind Crops Prod 86:173-179. https://doi.org/10.1016/j.indcrop.2016.03.047

17. Anand KGV, Kubavat D, Trivedi K, et al (2015) Long-term application of Jatropha press cake promotes seed yield by enhanced soil organic carbon accumulation, microbial biomass and enzymatic activities in soils of semi-arid tropical wastelands. Eur J Soil Biol 69:57-65. https://doi.org/10.1016/j.ejsobi.2015.05.005

18. Pamidimarri D, Sarkar R, Boricha G, Reddy M (2009) A simplified method for extraction of high quality genomic DNA from Jatropha curcas for genetic diversity and molecular marker studies

19. Doyle J, Doyle J (1990) Isolation of plant DNA from fresh tissue. Focus (Madison) 12:13-15

20. Lisec J, Schauer N, Kopka J, et al (2006) Gas chromatography mass spectrometry-based metabolite profiling in plants. Nat Protoc 1:387-396. https://doi.org/10.1038/nprot.2006.59

21. Paidi MK, Agarwal P, More P, Agarwal PK (2017) Chemical Derivatization of Metabolite Mass Profiling of the Recretohalophyte Aeluropus lagopoides Revealing Salt Stress Tolerance Mechanism. Mar Biotechnol 19:207-218. https://doi.org/10.1007/s10126-017-9745-9

22. Fajinmi AA, Fajinmi OB (2010) Incidence of okra mosaic virus at different growth stages of okra plants ([Abelmoschus esculentus (L.) Moench) under tropical condition. J Gen Mol Virol 2:28-031

23. Ascencio-lbáñez JT, Sozzani R, Lee TJ, et al (2008) Global analysis of Arabidopsis gene expression uncovers a complex array of changes impacting pathogen response and cell cycle during geminivirus infection. Plant Physiol 148:436-454. https://doi.org/10.1104/pp.108.121038

24. Góngora-Castillo E, Ibarra-Laclette E, Trejo-Saavedra DL, Rivera-Bustamante RF (2012) Transcriptome analysis of symptomatic and recovered leaves of geminivirus-infected pepper (Capsicum annuum). Virol J 9:295. https://doi.org/10.1186/1743-422X-9-295

25. Shalitin D, Wolf $S$ (2000) Cucumber mosaic virus infection affects sugar transport in melon plants. Plant Physiol 123:597-604. https://doi.org/10.1104/pp.123.2.597

26. Kim MS, Song MC, Eun YK, et al (2008) Galactinol is a signaling component of the induced systemic resistance caused by Pseudomonas chlororaphis 06 root colonisation. Mol Plant-Microbe Interact 
21:1643-1653. https://doi.org/10.1094/MPMI-21-12-1643

27. Loewus FA, Loewus MW (1983) myo-Inositol:Its Biosynthesis and Metabolism. Annu Rev Plant Physiol 34:137-161. https://doi.org/10.1146/annurev.pp.34.060183.001033

28. Srivastava A, Agrawal L, Raj R, et al (2017) Ageratum enation virus Infection Induces Programmed Cell Death and Alters Metabolite Biosynthesis in Papaver somniferum. Front Plant Sci 8:1172. https://doi.org/10.3389/fpls.2017.01172

29. Bazzini AA, Manacorda CA, Tohge T, et al (2011) Metabolic and miRNA Profiling of TMV Infected Plants Reveals Biphasic Temporal Changes. PLoS One 6:e28466. https://doi.org/10.1371/journal.pone.0028466

30. Lattanzio V, Lattanzio V, Cardinali A (2006) Role of Polyphenols in the Resistance Mechanisms of Plants Against Fungal Pathogens and Insects. In: Phytochemistry. pp 23-67

31. Meena RK, Patni V, Arora DK (2008) Study on Phenolics and Their Oxidative Enzyme in Capsicum annuum L. Infected with Geminivirus. Asian J Exp Sci 22:307-310

32. Jaiswal N, Singh M, Dubey RS, et al (2013) Phytochemicals and antioxidative enzymes defence mechanism on occurrence of yellow vein mosaic disease of pumpkin (Cucurbita moschata). 3 Biotech 3:287-295. https://doi.org/10.1007/s13205-012-0100-6

33. Kapoor S, Handa A (2018) Role of total phenolic compounds in inducing hypersensitive reaction against PNRSV in peach. J Pharmacogn Phytochem 7:766-768

34. Ros R, Muñoz-Bertomeu J, Krueger S (2014) Serine in plants: Biosynthesis, metabolism, and functions. Trends Plant Sci. 19:564-569

35. Llorens E, Camañes G, Lapeña L, García-Agustín P (2016) Priming by hexanoic acid induce activation of mevalonic and linolenic pathways and promotes the emission of plant volatiles. Front Plant Sci 7:495. https://doi.org/10.3389/fpls.2016.00495

36. Scalschi L, Vicedo B, Camañes G, et al (2013) Hexanoic acid is a resistance inducer that protects tomato plants against Pseudomonas syringae by priming the jasmonic acid and salicylic acid pathways. Mol Plant Pathol 14:342-355. https://doi.org/10.1111/mpp.12010

37. Crespo EF, Navarro JA, Soriano MS, et al (2017) Hexanoic acid treatment prevents systemic MNSV movement in cucumis melo plants by priming callose deposition correlating SA and OPDA accumulation. Front Plant Sci 8:1793. https://doi.org/10.3389/fpls.2017.01793

38. Roberts MR (2007) Does GABA act as a signal in plants? Hints from molecular studies. Plant Signal Behav 2:408-409. https://doi.org/10.4161/psb.2.5.4335

39. Scholz SS, Malabarba J, Reichelt M, et al (2017) Evidence for GABA-induced systemic GABA accumulation in arabidopsis upon wounding. Front Plant Sci 8:388. https://doi.org/10.3389/fpls.2017.00388

40. Wu N, Yang M, Gaur U, et al (2016) Alpha-ketoglutarate: Physiological functions and applications. Biomol. Ther. 24:1-8 


\section{Tables}

Table 1 The concentration of all the detected metabolites in healthy (control) and virus-infected Jatropha leaf tissue. The compounds that showed a significant decrease and increase (as determined by two paired sample t-test at $p<0.05$ ) of concentration in the infected tissue than healthy tissue are marked by

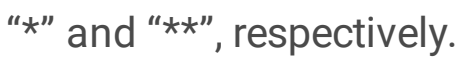




\begin{tabular}{|c|c|c|c|c|c|}
\hline \multirow{2}{*}{$\begin{array}{l}\text { Sr. } \\
\text { No. }\end{array}$} & \multirow[t]{2}{*}{ Name of compound } & \multicolumn{2}{|l|}{ Healthy tissue } & \multicolumn{2}{|l|}{ Infected tissue } \\
\hline & & $\begin{array}{l}\text { Concentration } \\
\text { ( } \mu \mathrm{g} / \mathrm{gm} \\
\text { tissue) }\end{array}$ & $\begin{array}{l}\text { SD } \\
( \pm)\end{array}$ & $\begin{array}{l}\text { Concentration } \\
(\mu \mathrm{g} / \mathrm{gm} \\
\text { tissue) }\end{array}$ & $\begin{array}{l}\text { SD } \\
( \pm)\end{array}$ \\
\hline & Common compounds & nfected tissue & & & \\
\hline 1 & Myo-Inositol* & 88.27 & 6.59 & 63.57 & 0.98 \\
\hline 2 & Sucrose & 55.23 & 5.85 & 66.85 & 2.04 \\
\hline 3 & Quinic acid* & 36.85 & 3.02 & 14.56 & 0.13 \\
\hline 4 & D-Glucose $e^{\star \star}$ & 34.29 & 2.58 & 43.55 & 0.72 \\
\hline 5 & Maltose & 29.12 & 0.77 & 30.43 & 0.53 \\
\hline 6 & Catechine & 26.48 & 1.93 & 25.97 & 0.21 \\
\hline 7 & Citric acid* & 26.29 & 1.66 & 13.81 & 0.46 \\
\hline 8 & Malic acid* & 25.07 & 1.69 & 8.53 & 0.14 \\
\hline 9 & Mannobiose & 23.20 & 2.44 & 20.59 & 0.04 \\
\hline 10 & Stearic acid* & 19.33 & 1.21 & 12.61 & 0.33 \\
\hline 11 & Glycerol & 16.32 & 0.57 & 15.89 & 0.23 \\
\hline 12 & D-Galactose oxime & 14.91 & 0.26 & 14.91 & 0.04 \\
\hline 13 & L-Threonic acid* & 14.08 & 0.36 & 10.03 & 0.08 \\
\hline 14 & Palmitic Acid* & 13.36 & 1.02 & 8.13 & 0.31 \\
\hline 15 & D-Gluconic acid & 13.23 & 1.61 & 15.52 & 0.57 \\
\hline 16 & D-Fructose** & 12.88 & 0.85 & 41.55 & 0.49 \\
\hline 17 & Galactinol* & 9.25 & 0.56 & 4.53 & 0.15 \\
\hline 18 & D-Trehalose* & 7.28 & 0.28 & 4.72 & 0.07 \\
\hline 19 & Glyceric acid** & 6.75 & 0.19 & 7.76 & 0.07 \\
\hline 20 & Quercetin** & 5.68 & 0.80 & 21.04 & 0.98 \\
\hline 21 & Dodecanol* & 4.53 & 0.53 & 1.95 & 0.59 \\
\hline 22 & Ribonic acid & 3.97 & 0.04 & 3.81 & 0.04 \\
\hline 23 & Galactaric acid & 3.97 & 0.46 & 1.63 & 0.04 \\
\hline 24 & Glutaric acid* & 3.92 & 0.17 & 0.16 & 0.00 \\
\hline 25 & L-Serine & 3.15 & 0.50 & 0.16 & 0.00 \\
\hline
\end{tabular}




\begin{tabular}{|c|c|c|c|c|c|}
\hline 26 & Docosanoic acid* & 3.01 & 0.08 & 0.61 & 0.10 \\
\hline 27 & Octatriacontyl pentafluoropropionate & 3.01 & 0.61 & 3.09 & 0.31 \\
\hline 28 & Glyceryl-glucoside** & 2.80 & 0.07 & 4.11 & 0.04 \\
\hline 29 & Butanoic acid & 2.69 & 0.21 & 2.61 & 0.19 \\
\hline 30 & meso-Erythritol & 2.53 & 0.15 & 2.03 & 0.04 \\
\hline 31 & Succinic acid* & 2.29 & 0.10 & 1.09 & 0.04 \\
\hline 32 & Triethylene glycol* & 2.08 & 0.11 & 1.33 & 0.04 \\
\hline 33 & 1-Decanol, 2-hexyl-* & 1.52 & 0.17 & 0.67 & 0.04 \\
\hline 34 & Shikimic acid & 1.20 & 0.20 & 1.44 & 0.11 \\
\hline 35 & L-Fucopyranose & 1.12 & 0.17 & 0.56 & 0.00 \\
\hline 36 & Glucopyranose** & 0.99 & 0.14 & 1.79 & 0.04 \\
\hline 37 & D-Mannitol & 0.99 & 0.10 & 0.96 & 0.00 \\
\hline 38 & Dodecane & 0.96 & 0.23 & 0.53 & 0.19 \\
\hline 39 & D-Lactose $e^{\star \star}$ & 0.96 & 0.11 & 2.05 & 0.04 \\
\hline 40 & Pentadecafluorooctanoic acid* & 0.80 & 0.11 & 0.35 & 0.04 \\
\hline 41 & Galactoside & 0.75 & 0.30 & 1.07 & 0.04 \\
\hline 42 & Protocatechoic acid & 0.72 & 0.13 & 0.93 & 0.04 \\
\hline 43 & Tetrapentacontane, 1,54-dibromo-* & 0.69 & 0.04 & 0.35 & 0.04 \\
\hline 44 & Diethylene glycol & 0.59 & 0.08 & 0.61 & 0.04 \\
\hline 45 & Deoxypentitol** & 0.59 & 0.08 & 1.63 & 0.04 \\
\hline 46 & Fumaric acid & 0.43 & 0.04 & 0.51 & 0.10 \\
\hline 47 & Butanetriol & 0.40 & 0.17 & 0.24 & 0.00 \\
\hline 48 & Methoxyacetic acid & 0.37 & 0.27 & 0.16 & 0.11 \\
\hline 49 & Isotridecyl alcohol & 0.08 & 0.00 & 0.08 & 0.00 \\
\hline & \multicolumn{5}{|l|}{ Compounds present only in healthy tissue } \\
\hline 1 & D-Galactopyranoside & 27.93 & 3.02 & - & \\
\hline 2 & 2-Ketoglutaric acid & 11.89 & 0.36 & -- & \\
\hline 3 & L-Threose & 8.24 & 0.80 & - & \\
\hline
\end{tabular}




\begin{tabular}{|c|c|c|c|c|c|}
\hline 4 & Allonic acid & 3.71 & 1.04 & - & \\
\hline 5 & D-Galacturonic acid & 2.98 & 0.22 & - & \\
\hline 6 & 4,6-Dioxatetradecane & 2.92 & 0.06 & - & \\
\hline 7 & Scyllo-Inositol & 2.79 & 1.13 & - & \\
\hline 8 & Pantothenic acid & 2.45 & 1.04 & - & \\
\hline 9 & L-Aspartic acid & 1.82 & 0.68 & - & \\
\hline 10 & alpha-Arabinopyranose & 1.57 & 0.12 & - & \\
\hline 11 & Epigallocatechin & 1.49 & 0.32 & - & \\
\hline 12 & 1-tert-Butoxy-2-propanol & 1.49 & 0.15 & - & \\
\hline 13 & L-Threonine & 1.41 & 0.26 & - & \\
\hline 14 & Benzaldehyde & 1.33 & 0.34 & - & \\
\hline 15 & Galactitol & 1.19 & 0.08 & - & \\
\hline 16 & L-5-Oxoproline & 1.09 & 0.86 & - & \\
\hline 17 & Hexadecyl isopropyl ether & 1.05 & 0.33 & - & \\
\hline 18 & Stigmasterol & 1.04 & 0.74 & - & \\
\hline 19 & Trichloroacetic acid & 0.81 & 0.12 & - & \\
\hline 20 & Probucol & 0.76 & 0.24 & -- & \\
\hline 21 & Dihydroxybutanoic acid & 0.68 & 0.08 & - & \\
\hline 22 & Pentanedioic acid & 0.49 & 0.07 & - & \\
\hline 23 & Tetracosane & 0.38 & 0.04 & - & \\
\hline 24 & 2,3-Butanediol & 0.32 & 0.17 & - & \\
\hline 25 & Citrulline & 0.27 & 0.14 & - & \\
\hline 26 & Batyl alcohol & 0.16 & 0.00 & - & \\
\hline 27 & Hexacontane & 0.08 & 0.07 & - & \\
\hline \multirow[t]{2}{*}{28} & D-Xylopyranose & 0.08 & 0.00 & -- & \\
\hline & \multicolumn{5}{|c|}{ Compounds present only in infected tissue } \\
\hline 1 & Hexonic acid & - & & 5.55 & 0.07 \\
\hline 2 & 4- Aminobutyric acid & - & & 3.81 & 0.22 \\
\hline
\end{tabular}




\begin{tabular}{|lllll|}
\hline 3 & D-Arabinose & - & 2.24 & 0.03 \\
\hline 4 & Levoglucosan & - & 1.76 & 0.03 \\
\hline 5 & D-Erythro-Pentitol & - & 1.43 & 0.00 \\
\hline 6 & D-Talopyranose & - & 1.19 & 0.07 \\
\hline 8 & Arabino-Hexos-2-ulose & - & 1.1 & 0.03 \\
\hline 9 & D-Psicose & - & 0.93 & 0.10 \\
\hline 10 & D-Cellobiose & - & 0.93 & 0.06 \\
\hline 11 & Urea & - & 0.86 & 0.00 \\
\hline 12 & 1,5-Anhydrohexitol & - & 0.79 & 0.46 \\
\hline 13 & 2-Furanacetaldehyde & - & 0.67 & 0.03 \\
\hline 14 & Erythrono-1,4-lactone & - & 0.64 & 0.00 \\
\hline 15 & Palatinose & - & 0.6 & 0.03 \\
\hline 16 & Valine & - & 0.55 & 0.09 \\
\hline 17 & Thiophene & - & 0.31 & 0.29 \\
\hline 18 & 3-Methylene-1,4-bis(trimethylsilyloxy) & - & 0.31 & 0.03 \\
\hline 19 & butane & - & 0.29 & 0.00 \\
\hline 20 & 3,9-Dioxa-2,10-disilaundecane & - & 0.29 & 0.00 \\
\hline 21 & 3-Hydroxyisovaleric acid & - & 0.14 & 0.00 \\
\hline
\end{tabular}

Table 2 The fold change in the common metabolites in infected tissue as compared to healthy tissue of Jatropha. 


\begin{tabular}{|c|c|c|c|c|c|}
\hline \multirow{2}{*}{$\begin{array}{l}\text { Class of } \\
\text { Compound }\end{array}$} & \multirow{2}{*}{$\begin{array}{l}\text { Sr. } \\
\text { No. }\end{array}$} & \multirow[t]{2}{*}{ Compound name } & \multicolumn{2}{|c|}{ Concentration } & \multirow{2}{*}{$\begin{array}{l}\text { Fold } \\
\text { Change }\end{array}$} \\
\hline & & & Healthy & Infected & \\
\hline \multirow[t]{12}{*}{ Sugars } & 1 & L-Fucopyranose & 1.12 & 0.56 & -2 \\
\hline & 2 & D-Trehalose & 7.28 & 4.72 & -1.54 \\
\hline & 3 & Glyceryl-glucoside & 2.8 & 4.11 & -1.47 \\
\hline & 4 & Mannobiose & 23.2 & 20.59 & -1.13 \\
\hline & 5 & D-Galactose oxime & 14.91 & 14.91 & 1 \\
\hline & 6 & Maltose & 29.12 & 30.43 & 1.04 \\
\hline & 7 & Sucrose & 55.23 & 66.85 & 1.21 \\
\hline & 8 & D-Glucose & 34.29 & 43.55 & 1.27 \\
\hline & 9 & Galactoside & 0.75 & 1.07 & 1.43 \\
\hline & 10 & Glucopyranose & 0.99 & 1.79 & 1.81 \\
\hline & 11 & D-Lactose & 0.96 & 2.05 & 2.14 \\
\hline & 12 & D-Fructose & 12.88 & 41.55 & 3.23 \\
\hline \multirow[t]{14}{*}{ Carboxylic acids } & 13 & Glutaric acid & 3.92 & 0.16 & -24.5 \\
\hline & 14 & Malic acid & 25.07 & 8.53 & -2.94 \\
\hline & 15 & Quinic acid & 36.85 & 14.56 & -2.53 \\
\hline & 16 & Galactaric acid & 3.97 & 1.63 & -2.44 \\
\hline & 17 & Methoxyacetic acid & 0.37 & 0.16 & -2.33 \\
\hline & 18 & Pentadecafluorooctanoic acid & 0.8 & 0.35 & -2.31 \\
\hline & 19 & Succinic acid & 2.29 & 1.09 & -2.1 \\
\hline & 20 & Citric acid & 26.29 & 13.81 & -1.9 \\
\hline & 21 & L-Threonic acid & 14.08 & 10.03 & -1.4 \\
\hline & 22 & Ribonic acid & 3.97 & 3.81 & -1.04 \\
\hline & 23 & Glyceric acid & 6.75 & 7.76 & 1.15 \\
\hline & 24 & D-Gluconic acid & 13.23 & 15.52 & 1.17 \\
\hline & 25 & Fumaric acid & 0.43 & 0.51 & 1.19 \\
\hline & 26 & Shikimic acid & 1.2 & 1.44 & 1.2 \\
\hline Polyols & 27 & Galactinol & 9.25 & 4.53 & -2.04 \\
\hline
\end{tabular}




\begin{tabular}{|c|c|c|c|c|c|}
\hline & 28 & Butanetriol & 0.40 & 0.24 & -1.66 \\
\hline & 29 & Triethylene glycol & 2.08 & 1.33 & -1.56 \\
\hline & 30 & Myo-Inositol & 88.27 & 63.57 & -1.39 \\
\hline & 31 & meso-Erythritol & 2.53 & 2.03 & -1.25 \\
\hline & 32 & D-Mannitol & 0.99 & 0.96 & -1.03 \\
\hline & 33 & Glycerol & 16.32 & 15.89 & -1.03 \\
\hline & 34 & Diethylene glycol & 0.59 & 0.61 & 1.05 \\
\hline & 35 & Deoxypentitol & 0.59 & 1.63 & 2.77 \\
\hline Fatty acids & 36 & Docosanoic acid & 3.01 & 0.61 & -4.91 \\
\hline & 37 & Palmitic Acid & 13.36 & 8.13 & -1.64 \\
\hline & 38 & Stearic acid & 19.33 & 12.61 & -1.53 \\
\hline & 39 & Butanoic acid & 2.69 & 2.61 & -1.03 \\
\hline & 40 & $\begin{array}{l}\text { Octatriacontyl } \\
\text { pentafluoropropionate }\end{array}$ & 3.01 & 3.09 & 1.03 \\
\hline Polyphenols & 41 & Catechine & 26.48 & 25.97 & -1.02 \\
\hline & 42 & Protocatechoic acid & 0.72 & 0.93 & 1.3 \\
\hline & 43 & Quercetin & 5.68 & 21.04 & 3.7 \\
\hline Fatty alcohols & 44 & Dodecanol & 4.53 & 1.95 & -2.33 \\
\hline & 45 & 1-Decanol, 2-hexyl- & 1.52 & 0.67 & -2.28 \\
\hline & 46 & Isotridecyl alcohol & 0.08 & 0.08 & 1 \\
\hline Alkanes & 47 & Tetrapentacontane, 1,54-dibromo- & 0.69 & 0.35 & -2 \\
\hline & 48 & Dodecane & 0.96 & 0.53 & -1.8 \\
\hline Amino acids & 49 & L-Serine & 3.15 & 0.16 & -19.67 \\
\hline
\end{tabular}

\section{Figures}


A)

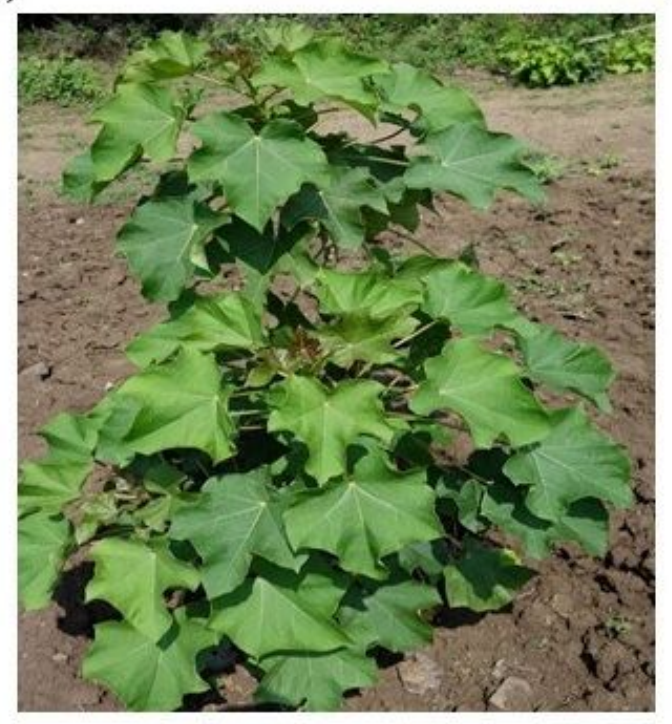

B)

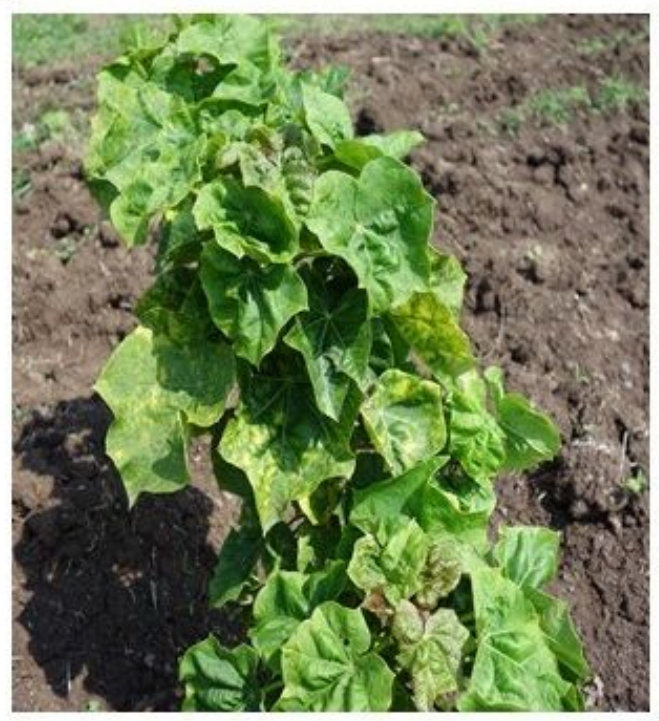

C)

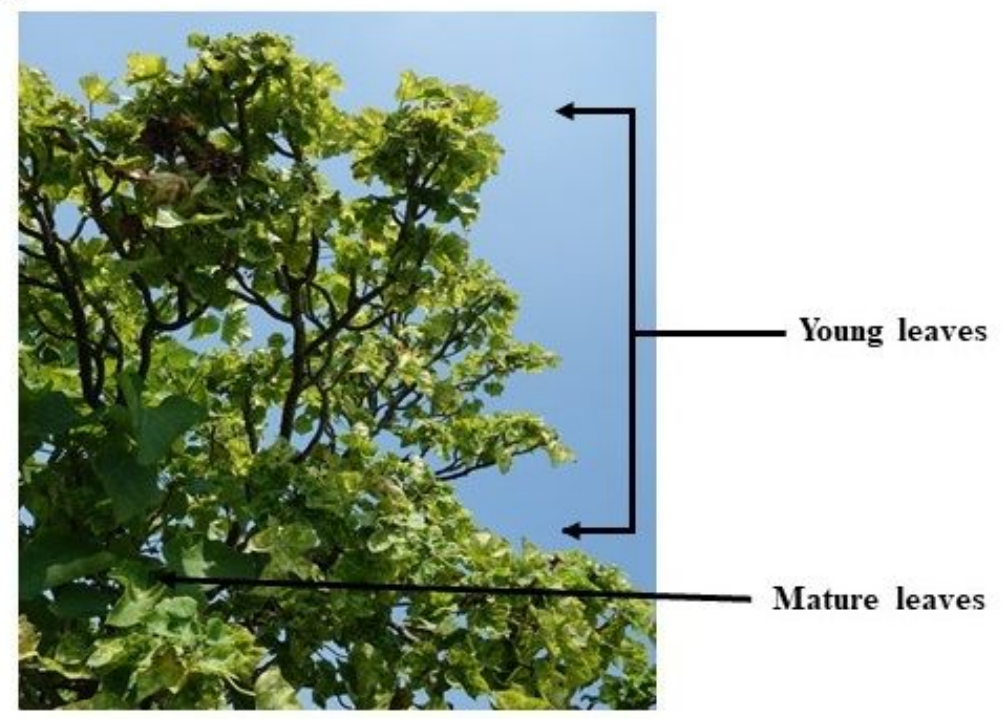

D)

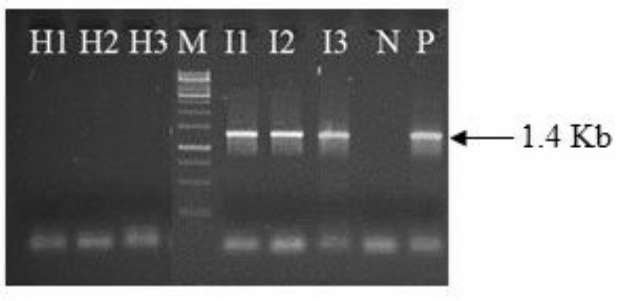

\section{Figure 1}

The Jatropha plants showing the leaf yellow mosaic curl symptoms. (A) healthy Jatropha plant, (B) young plant showing the mosaic-curl symptoms in all leaves, and (C) mature plant having both healthy (mature leaves) and mosaic-curl symptoms (younger leaves), (D) Detection of geminivirus infection using PCR in Jatropha leaf samples collected from Nesvad (lane H1, H2, H3: healthy leaf samples; Lane I1, I2, I3: infected leaf samples, N: negative, P: positive sample; M: 1 Kb DNA ladder. 
A)

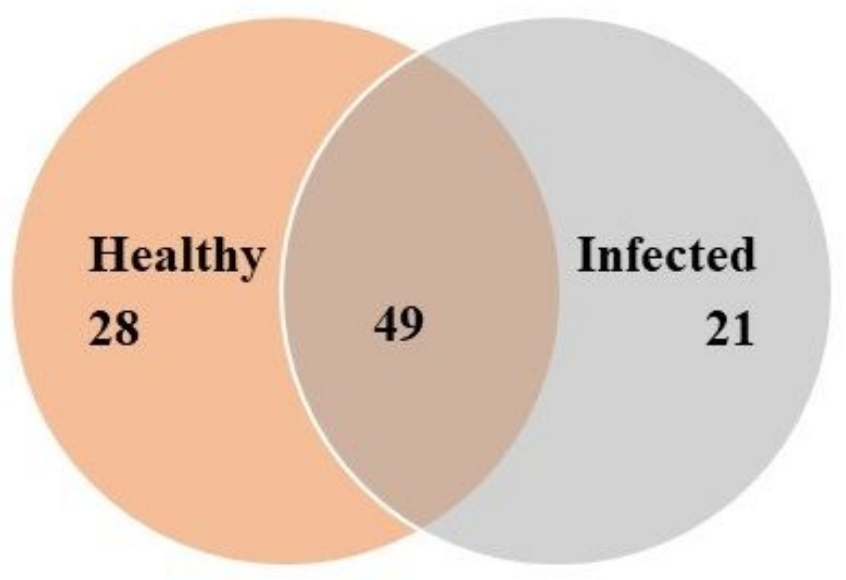

B)

\section{Healthy}

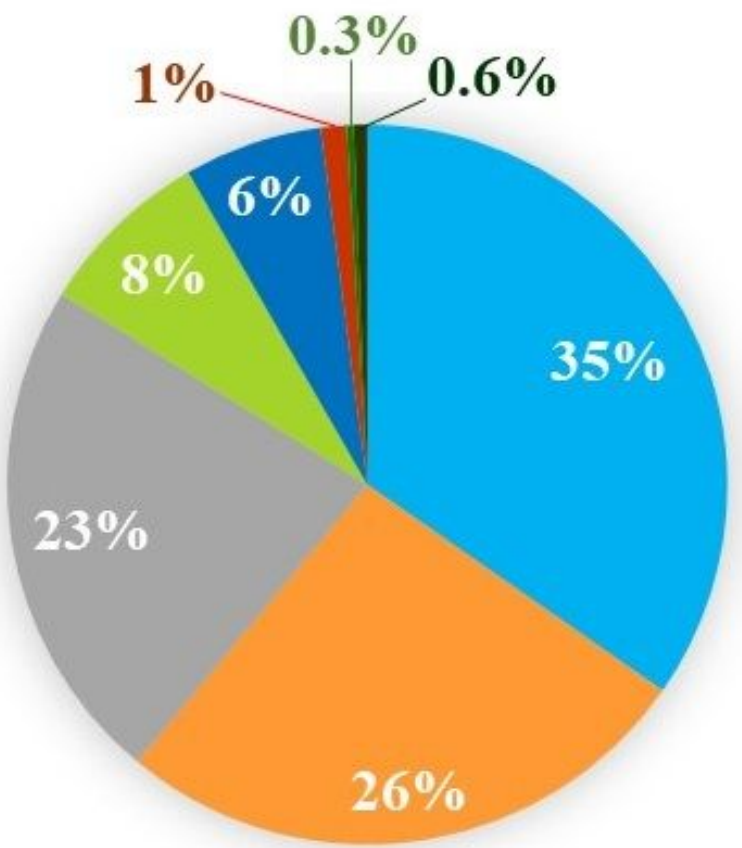

- Sugars

- Polyphenols
- Carboxylic acids = Polyols

- Fatty alcohols

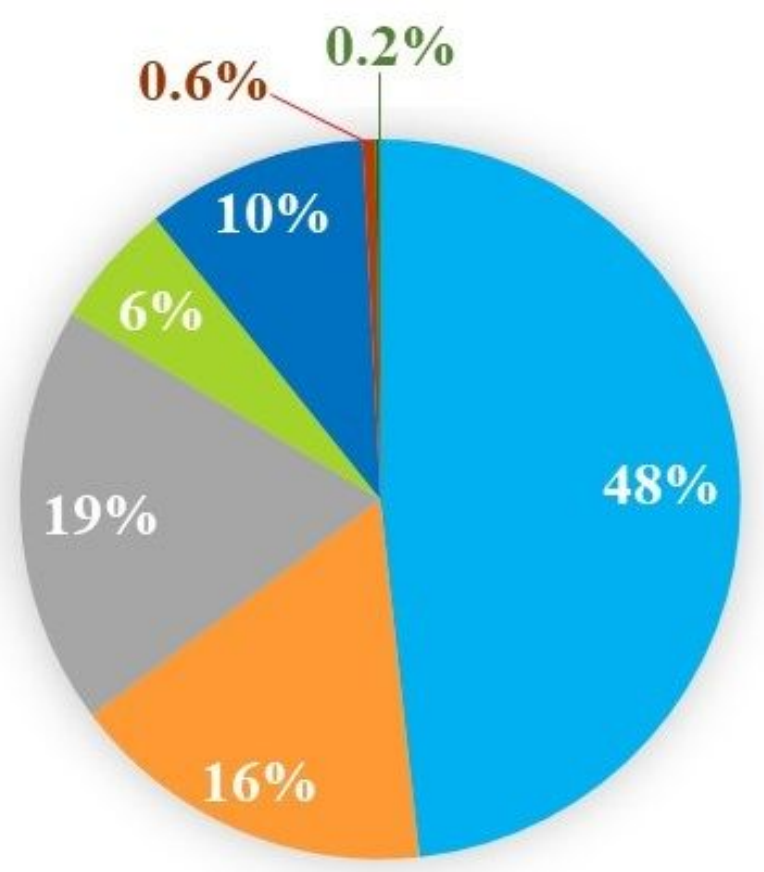

Alkanes

Infected

$0.2 \%$

Fatty acids

- Amino acids

\section{Figure 2}

Distribution of detected metabolites in healthy and infected tissue of Jatropha. (A) Venn diagram showing the common and unique compounds identified in healthy and infected tissue, (B) the percentage distribution of metabolites according to their class in healthy and infected tissue. 


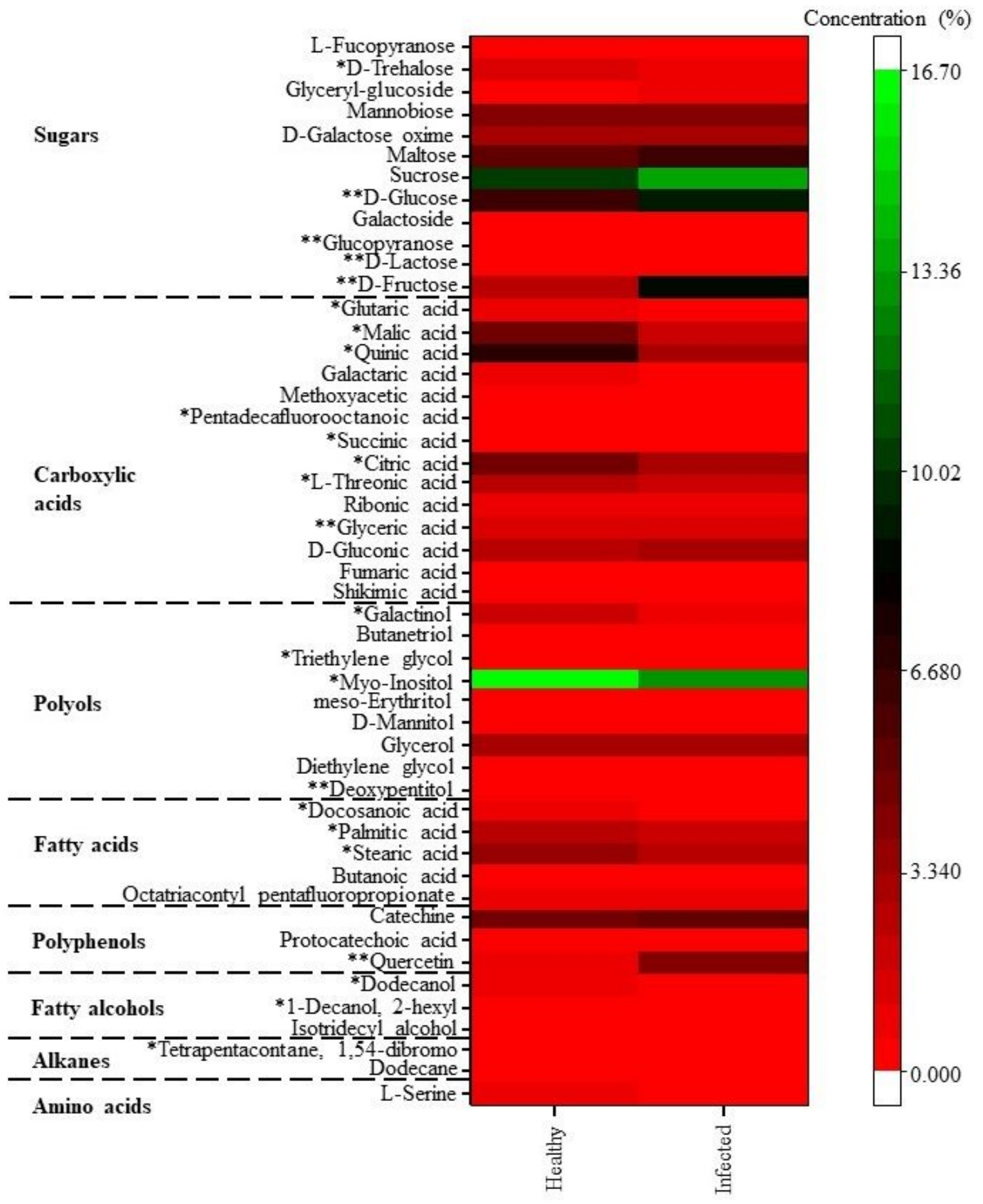

\section{Figure 3}

Heat map showing the concentrations of different metabolites detected in both healthy and infected tissue. The metabolites which showed a significant decrease and increase (as determined by two paired sample t-test at $p<0.05)$ in infected leaf tissue are marked with " $"$ " and " $\star \star "$, respectively. 


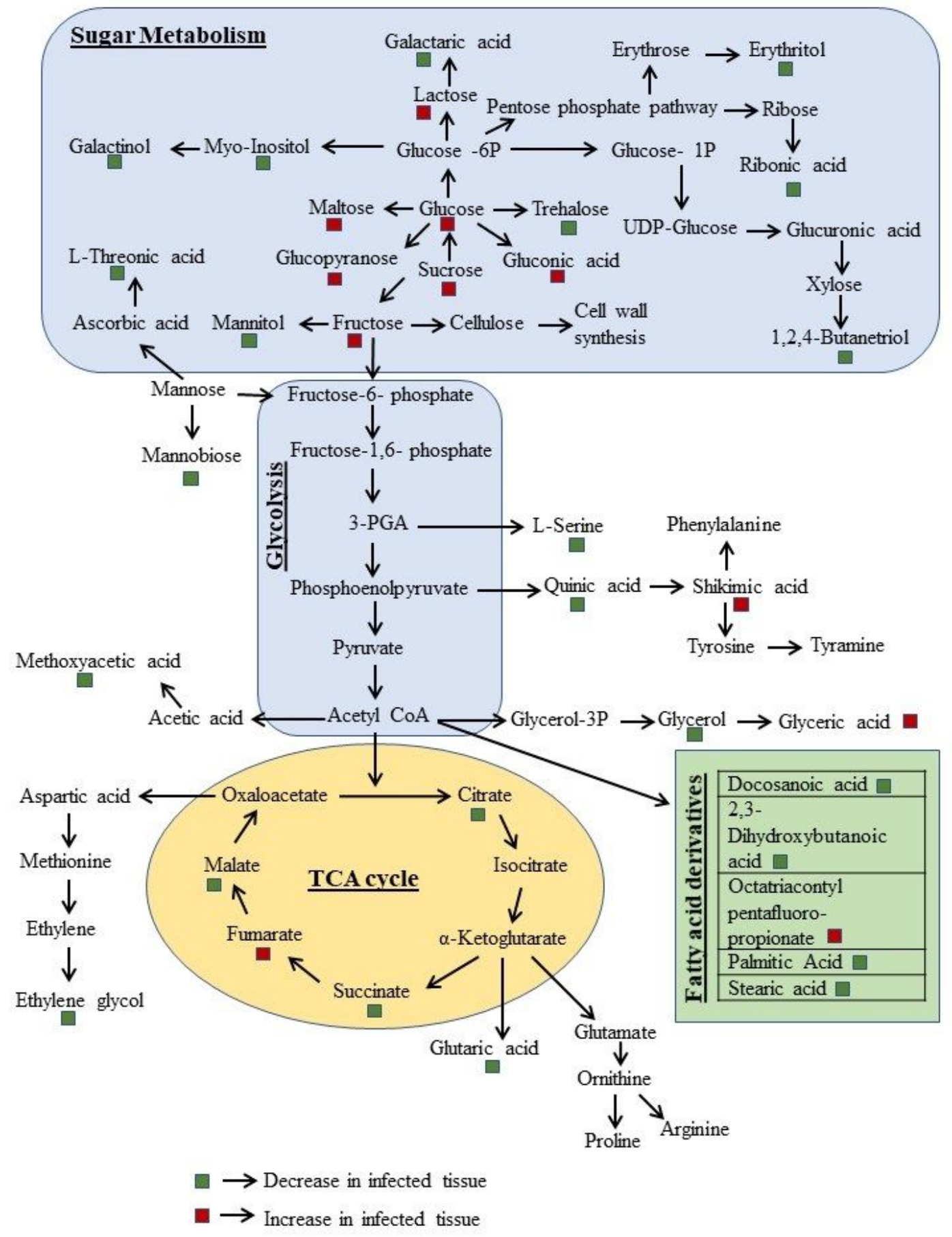

\section{Figure 4}

The metabolite flux pathway depicting the sugar metabolism and TCA cycle. The decreased and increased concentration of a metabolite in infected tissue was depicted by green and red coloured square boxes, respectively. The untagged metabolites were not detected in the present study. 